\title{
Tactical Urbanism Where it Matters: How Small Scale Spatial Practice Can Catalyze Change in Underserved Communities
}

\author{
SALLY HARRISON \\ Temple University
}

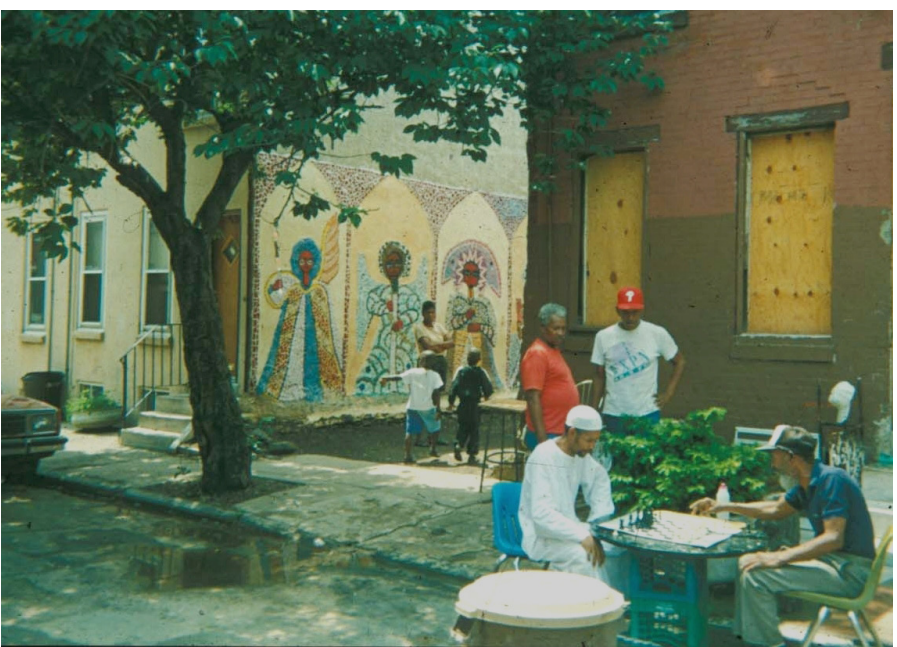

Figure 1. Alder Street, the Village of Arts and Humanities in North Philadelphia. Men playing chess near Angel Alley. Photo: S. Harrison

Small scale spatial interventions that bring vibrancy to city life have been a preoccupation of designers in recent years. While creative actions have focused on the almost-healthy environment, what of those communities perennially underserved, and whose problems of poverty, crime, health and environmental decay are more complex and challenging? Through several case studies, this paper examines a new direction for the spatial practice known as "tactical urbanism," and suggests that it might catalyze change in distressed communities if undertaken with careful consideration of multiple systems that form these contexts. Design collaborations, cooperative research and willingness to expand the temporal frame of a project can help to catalyze institutional growth and neighborhood stability. (Fig. 1)

\section{INTRODUCTION: TACTICAL URBANISM AND THE CREATIVE CLASS}

In 2005 a collaborative of artists and designers paid for two hours at a parking meter, and installed in its twenty by nine-foot space turf, chairs and a potted tree. Inspired by the stealth interventions by artists like Banksey and the Situationists, the installation by the San Francisco group Rebar, was a critique of cultural values embedded in the use of urban space. (1) The idea of natural and human elements invading the space for car storage, of people finding a pleasurable respite in a parking space became iconic. Images went viral.

In two years this spatial detournement had become an international event: Park(ing) Day became an opportunity for young designers to express their creativity and assert their, and others', right to claim public space, if only briefly. Rebar's instant global success is often cited as the beginning of the movement called "tactical urbanism" (2). Employing small-scale, short term interventions to build vibrancy in city life and "seed structural environmental change" tactical urbanism tapped into the estrangement of the common citizen from having a role in shaping cities (3). Its practices were eagerly adopted by planners, architects, artists and landscape architects, attracted by the hands-on process that brought immediacy and visibility to the opacity of urban transformation. Running the gamut from stealth spatial works by urban artists to orchestrated placemaking by teams of design professionals and policy-makers, the once-subversive practice has become a staple of urban design.

The abundance of novel, engaging interventions made and enjoyed by members of the young creative class has attracted city leaders and developers who seek opportunities to invigorate city centers and to promote gentrifying neighborhoods with an allure of hipness. Pop-up markets and beer gardens, chair-bombing, hand-made way-finding tactics, downtown beaches, unsanctioned bike-lanes have become a staple of casual chic urbanism in cities worldwide -- a brand itself, rather than what had begun as a spontaneous, community-generated activist practice Indeed, naming the practice "Tactical Urbanism" with the tag line "lighter, quicker, cheaper" ("LQC" in the parlance of the Project for Public Places) has been popularized in various media and exhibited in prestigious venues, guaranteeing mainstream acceptance (4). Almost as quickly as the edgy practice burst on the scene, it was adopted as a marketing tool by the neoliberal urban culture (5).

\section{INFORMALITY AND URBAN SPACE}

But urban tactics have been around as long as there have been cities. And mostly not for and by a privileged class. The street vendor, the sidewalk 
lounger, the child at play, the graffiti artist, the squatter, the guerrilla gardener - all have taken their corner of the city and appropriated it for individual or collective use (6). Most have found necessity to be the mother of their creative inventions, and have used the city opportunistically finding unclaimed space, using available materials, bending the rules to accommodate needs unmet by the powers that plan and organize their environment. Without self-celebration these urban tacticians operate in what De Certeau calls the drifts and ellipses of the urban order - bypassing or overwriting with lived experience the formal strategies of the top-down city (7).

And while tactical urbanism has deep roots in ages-old informal practices of urban dwellers, its current iteration is more probably a continuation of reaction to heavy-handed planning and bureaucracy. De Certeau, Lefebvre, Rudofsky, Alexander, Jacobs, Team Ten and others had powerfully articulated the loss of human touch that top-down city-building imposed on everyday life. Said Aldo van Eyck:

"The material slum has gone ... but what has replaced it? Just mile upon mile of organized nowhere, and nobody feeing he is 'somebody living somewhere'. No microbes left -yet each citizen a disinfected pawn on a chessboard, but no chessmen- hence no challenge, no duel no dialogue. The slum is gone. Behold the slum edging into the spirit....Architects have left no cracks and crevices this time. They expelled all sense of place. Fearful as they are of the wrong occasion, the unpremeditated event, the spontaneous act...." (8)

In the postwar decades the call to human-centered design provoked study of vernacular urban form and everyday spatial practices in nonwestern contexts, but also in the epicenter of corporate power, New York City. Partly due to his accessible language and non-threatening tone, and partly to the rigor of his observational methods, William Whyte's contributions over several decades have helped to popularize an understanding of urban dynamics reemerging now. Broadly proliferated, Whyte's observations astutely (and often hilariously dated) point out simple truths about informal, spontaneous use of highly formal space: access to food, moveable seating and "triangulation" (9). It is not surprising that Whyte has become the godfather of the tactical urbanism/placemaking movement (10).

\section{TACTICAL URBANISM: FOR WHOM?}

Though Whyte's work is important, it is benign and relatively apolitical. He opens his film "The Social Life of Small Urban Spaces" showing the street life in Harlem, but it is a sentimental depiction with "no challenge, no duel" that would address the larger inequities of urban space. With some notable exceptions tactical urbanist and placemaking projects have chiefly concerned themselves with activating underutilized space in already healthy, well-served environments (11). Indeed, prerequisite conditions are cited in the Project for Public Spaces website: "Once components like accessibility, safety, and overall comfort have been addressed, it may be the right moment to think about some LQC strategies" (12). That excess of caution certainly contradicts the movement's stated desire to seed structural environmental change in a significant way; it precludes those places that may most urgently need well-designed catalytic interventions. In underserved urban neighborhoods accessibility, safety and overall comfort are among the chief issues that undermine active social spaces that build community. In addition, high household poverty levels and inadequate public funding suggests that what is lighter quicker and cheaper is most often the only option. In light of this, a discussion about a new iteration of tactical urbanism in places where it really matters, is potentially important and timely.

This paper looks at the Philadelphia area, including Camden New Jersey, where tactical interventions have been constructed in the healthy center and in gentrifying neighborhoods, but also in critically underserved communities where a constellation of poverty-generated conditions is present as a fact of daily life. Philadelphia on the whole is undergoing a transformation from a post industrial city in precipitous decline to a city with a vigorous knowledge-based economy and a growing population. Suburban empty-nesters and well-educated millennials have taken up residence in Philadelphia's downtown and hip "emerging" neighborhoods. More affordable and arguably more tractable than New York and Washington DC, a young urban "creative class" has opened restaurants, expanded the art scene and pushed for social spaces in the city (13). Tactical urbanist projects abound as edgy public art, pop-up city "beaches", street fairs and beer gardens proliferate. These figured prominently in the Huffington Post's enumeration of the "Twenty-one Reasons why Philadelphia is the Coolest City in America" (14).

In their essays for the exhibition of the US Pavilion at the 2012 Venice Biennale "Spontaneous Interventions: Design Actions for the Common Good", Tom Angotti and Gordon Douglas both warn of the potential for tactical intervention to become an agent of gentrification and displacement. Says Douglas:

"Should we consider the possibility that these design interventions for the common good may indeed, just like official improvements, still contribute to an uneven development of their own? That the very arrival of such actions (and their creators) might precipitate or even encourage the gentrification process in one place, or be viewed as quite unwelcome in another?" (15)

Indeed, this appears to have happened as the recession abated and designers have rejoined mainstream practice. Philadelphia's most visible tactical urbanist projects are now largely in the hands of commercial, and thus official, city interests, cleansed of the explicitly activist, grassroots aspiration for a non-exploitative "generous urbanism" that Rebar's Merker speaks of (16). Vaguely reminiscent of a suburban backyard barbecue, the beer garden with its picnic tables, umbrellas and Adirondack chairs the much replicated pop-up beer garden-in-vacant-lot tactic has been seized by the development community. And perniciously it has become a strategy for attracting young, white millennial gentrifiers into relatively stable African American neighborhoods where they might otherwise feel uncomfortable living. Recognizing what is at stake residents have resisted, but to no avail, as the cleaned-up vacant lots with their funky recycled furnishings are already owned, and planned for expensive condominiums (17).

The ascendancy of the creative class notwithstanding, there is another Philadelphia narrative where the uneven distribution of resources is 
astonishing. Philadelphia's twenty-six percent poverty rate exceeds that of the ten largest cities in the US, and closely neighboring Camden New Jersey is the poorest city in the country. There is deep unemployment, the predominance of single-parent households with high numbers of children, low educational attainment, and poor health. Consistently, residents report the isolating impact of the drug culture and criminal activity and the erosive effects that the concentration of untended vacant lots have in their neighborhoods (18). These are not conditions in which small, temporary acts of design intervention can easily ignite significant change. But nevertheless a close observation of habitus provides a more hopeful perspective. Even-- and especially--in these most deeply underserved neighborhoods there are patterns of citizen pro-action that are creative and pragmatic responses to need and opportunity found in the environment; here as in impoverished neighborhoods around the world, in Cathy Lang Ho's words, "what we call tactical urbanism is simply a way of life"(19). Designers with a commitment to broader social impact might find ways to collaborate with communities, using urban tactics to tap veins of unrealized urban possibility.

So, how can a new version of tactical urbanism be employed to advance a social justice agenda and reclaim its democratizing effects? How, outside the centers and contested urban edges, can small scale design-interventions address the multi-layered quality-of-life issues born of poverty and public underinvestment? What must be added to the "spontaneous" act of intervention to make sure that it knowingly engages larger spatial, socio-economic and temporal contexts? Who participates, and how do designers, who are mostly outsiders, operate? With these questions I will examine three case studies in Philadelphia and Camden New Jersey.

\section{STRATEGIES AND TACTICS}

Questions of context, especially social, temporal and economic, were foregrounded in a recent design collaboration between Temple University's Urban Workshop studio consisting of architecture and planning students and the nearby community development corporation, Asociacion Puertorriquenos en Marcha. The studio project called "Urban Acupuncture: Strategies and Tactics" drew on Lerner's and Casagrande's notion that to catalyze change a deep understanding of the interlaced systems of place provides the essential knowledge of how and where to intervene(21). Students were charged with proposing urban design interventions that engage neighborhood issues as a whole, and that elements of a long-term plan be distilled into tactical projects that could be realized in the short term.

Neighborhood research took place on the ground and built on layers of previous investigation by APM, situating it in planning and design strategies found in other urban communities (22). Our client team included economic development and social welfare workers who gave the studio members community access and linkages with nutrition and entrepreneurship programs. Design, both large scale and small was born of the confluence of multiple neighborhood-specific needs. Students crafted proposals for a key block of a disused commercial corridor that had once been at the heart of Philadelphia's industrial production and had provided jobs for local residents until the mid-20th century decline in manufacturing. The current $27 \%$ unemployment rate, and the average household income of $\$ 15,000$ and under-educated adult population suggested that strategies to increase household wealth through low threshold job opportunities would be the most valuable contribution to overall community health.

Research uncovered patterns of existing informal micro-economic activity and broader potential systemic synergies that might seed new community-owned businesses. The practices of gardening and of repairing cars and bicycles in vacant lots, of conducting daycare, by-the-meal catering or seamstress services in-home, and of making the short walk to Temple University for (usually low-wage) jobs, were common. The puzzling frequency of small podiatric offices was quickly understood to be a result of the diabetes epidemic flourishing in an environment where pedestrian activity was inhibited by fear of crime, and access to healthy foods was limited.

Taken together these observations yielded an unconventional set of responses to the development of a commercial corridor. Rather than a retail center it might have created community wealth building power as an entrepreneurship hub. Evoking the multi-story manufacturing loft typology, a vertical aquaponics farm was proposed; with ten times the growing efficiency of a community garden, the farm would produce year round, selling directly to residents and supplying local stores, bringing down the cost of fresh vegetables and fruits and spinning off a small healthy foods restaurant owned by local caterers. The abundance of informal in-home daycare providers serving the very high number of small children, and a new mayor's policy to dramatically expand Headstart programs, suggested a new flagship childcare training facility to bring up the quality of in-home care throughout the community while providing a convenient center for those working in the new entrepreneurship hub.

Recognizing the University as an immense consumer of services and an untapped resource, the students proposed a co-operatively owned laundry that would replace at least in part the University Hospital's practice of shipping its linens 300 miles away. The University was also a generator of cast off goods - clothing, bicycles and furnishings were left behind by the truckload by students- and the neighborhood skills in sewing, mechanics and repair led to proposals for upcycling businesses that could depend on a steady stream of free raw material. Bicycle repair could be linked with a recreational circuit connecting with the child care facility, and with new bike lanes and a bike-park already proposed by the city.

Parallel to the activities of the Urban Workshop Studio our client at APM was conducting business-creation training for motivated community members with the kinds of skills that informed the design proposals. $\mathrm{He}$ asked that we preserve the DNA of each of the programs developed at the urban design scale and recreate them as a mini-entrepreneurship hub called the Pop-Up Marketplace Project (PUMP) on a vacant lot on the corridor, with the hope that the tactical interventions that would jump start growth. Through the Port of Philadelphia, he had gotten access to lightly used shipping containers and the students proposed adaptive designs for their adaptation that were carefully designed for porosity and security, for functionality, sustainability and style: The Grow Box, The ReFab studio; The Spoke and Hub bike repair, etc. One container dubbed the Toy 


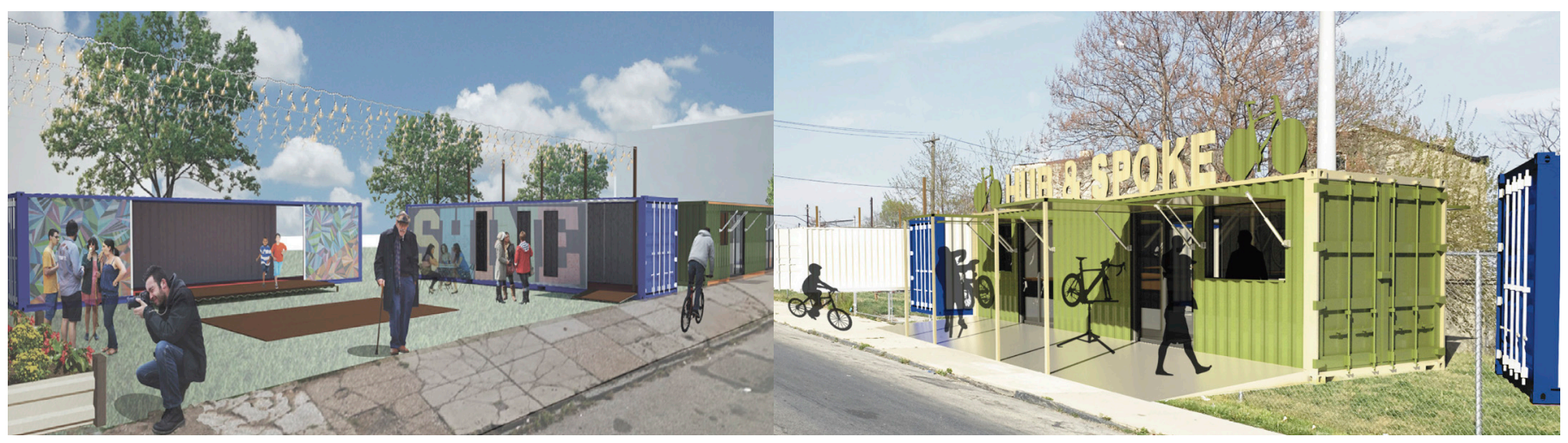

[Figure 2. Pop-Up Marketplace with containers for start-up businesses. and a family-oriented Toy Box. Images: Dan Vallachi and Nick Scassaro

Box was designated for a variety of community uses, from a children's camp by day to a music venue by night, keeping the as-yet undeveloped site a lively destination. While each container would house a particular business, together they were deployed to engage the street and create shared outdoor space. (Fig. 2)

At this writing the training is being completed and an installation is expected in the spring of 2017. That will be the test. But what has been learned is that the tactical urbanist project in a location so challenged, cannot simply draw on the now-predictable social-space tropes to transform quality of life, but must be part of a layered process of research into multiple contexts (social, economic and spatial) and design-thinking with long term goals in mind (increase the mean wealth of local households). Moreover, in underserved communities the tactical project itself cannot be a no-risk proposition. However much it may be lighter, quicker and cheaper, it is a commitment of some significance. It must be well-designed because as one of the project funders observed, what is temporary often becomes permanent...

\section{PLAY, TACTICS IN THE INTERSTICES}

Across the city, a tactical urbanist project is evolving on Lancaster Avenue another struggling commercial corridor. Here, play is a vehicle for social and physical health, and for hands-on making as an education process. The project called "Play Lancaster", is led by Public Workshop a design collaborative that teaches youth from underserved communities" skills in building and designing urban space. Eschewing the guerilla-designer as Robin Hood role, Public Workshop is more akin to a Pied Piper drawing enthusiasts and skeptics alike into a collective ethos of placemaking. The group has an established collaborative history with the local CDC that has been at work on revitalization strategies for the Avenue, and now they co-inhabit a storefront near the play site, a visible long term commitment to the neighborhood and the evolution of the project (23).

The neighborhood-generated idea for Play Lancaster began with an empty lot that seemed perfect for a playground. But the 80 -foot wide by 100 -foot deep lot defied the security principles of natural surveillance: no surprise that it was soon revealed as a nighttime drug hangout.
Undeterred, Public Workshop and its young crew first enclosed the deep back of the lot with a decorative see-through fence with a large lockable gate, reducing the play area to a ten-foot band along the Avenue. The enclosed space became a seasonal workshop for future community design-build projects. The street-front play scape is a quirky, fun and informal public space. They have furnished it with a community chalk board, a platform with table for eating and relaxing, a "switchback play bench", a mini-fort and simple exercise equipment. (Fig. 3) Counter to the traditional design of playgrounds as unique bounded spaces, the play space spills out on to the street for hopscotch and other pavement games. It operates in the spirit of Christopher Alexander's observation: "Play takes place in the interstices of adult life. As they play children become full of their surroundings..." (24). Indeed, the sidewalk is where city kids, instinctive tacticians, have always played - out in the carnival of street life, but also under the watchful eye of parents and neighbors.

Understanding the ecosystem of the neighborhood, Public Workshop saw the potential for this tactical intervention to both thrive and to have a critical impact at a larger scale. Despite its reputation as a tough corner, the project's specific location is propitious: directly adjacent is a popular deli, across the street are a daycare and after school center, and around the corner a charter school, all filled with kids who gravitate to the site.

The founder of Public Workshop says he wants to "rewire the community engagement process" by making it tangible, visible and animated by the creative energy of youth. While at work on Lancaster Avenue, the crew drew wide participation from diverse members of the community: some helped build, some set up chessboards, some gave advice. Some were part of the very drug culture whose space the project had appropriated; but as is common, they were often members of families of participants, and they became invaluable as guardians of the site (25).

\section{TEST BEFORE YOU INVEST: REIMAGINING THE PUBLIC REALM IN CAMDEN}

Nowhere are the challenges to the public realm as evident as in Camden, New Jersey. Directly across the Delaware River it shares with Philadelphia the distinction as an active port city. It is as well the home of an important university and hospital; but these assets cannot compensate for the depth of its poverty. The crisis of identity, of truly belonging neither to Philadelphia nor New Jersey is painfully clear in its 


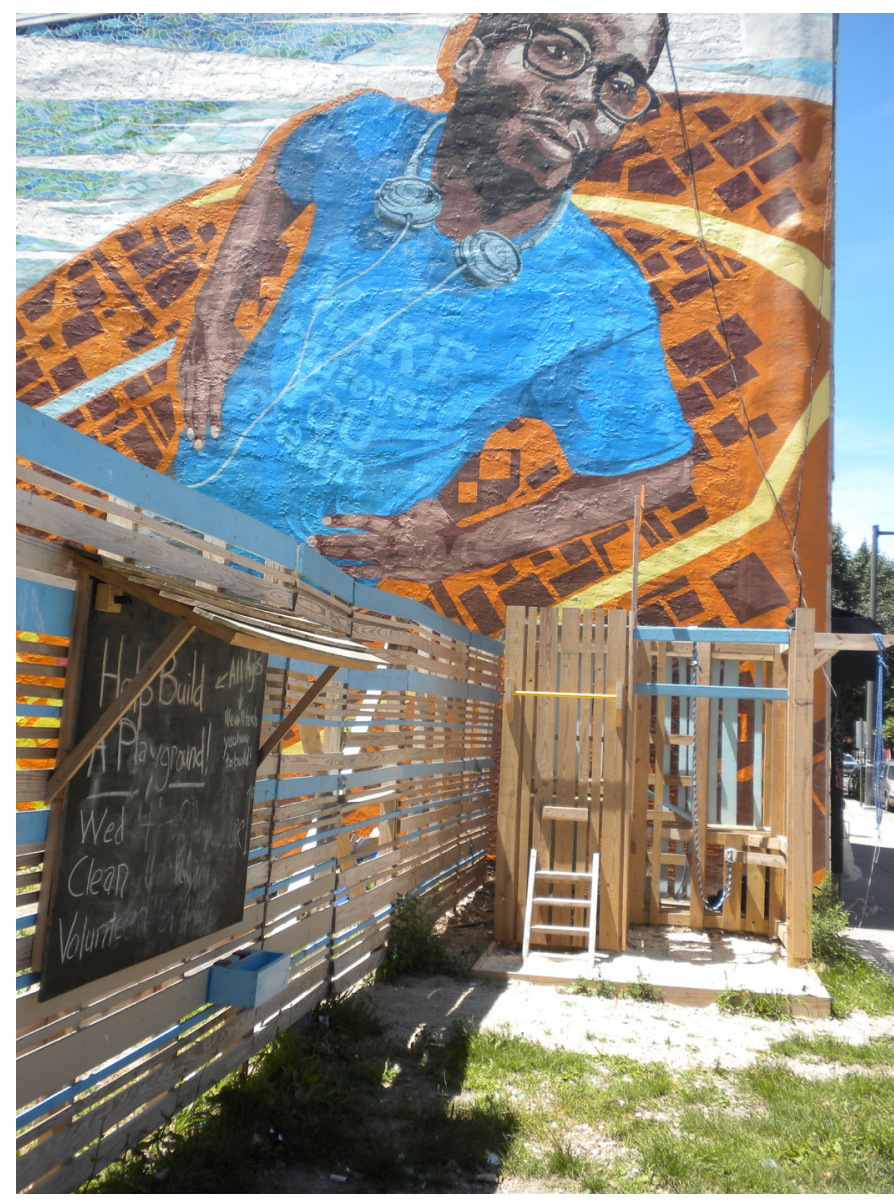

Figure 3. Play Lancaster. The project was built with neighborhood youth as a strip along the commercial corridor. Photo: S. Harrison

active recreational waterfront whose public spaces and amenities unapologetically turn their backs on the city. But in the experimental Roosevelt Plaza Pop-Up in the heart of Camden facing City Hall, democratic access to public space is the driver. The two acre Roosevelt Plaza Park had replaced a demolished parking garage, but was only a wind-swept walk-through with few amenities that would build community and civic identity. Led by a public-private partnership and designed by landscape architects and planners Sikora Wells Appel and the Melvin Group, the seasonal "pop-up" is ambitious and innovative in terms of design, program and research. Its tactics serve the placemaking principle of "test before you invest" famously used in the Times Square project, but now in a very different in context: the site is bordered by City Hall, a large methadone clinic, a Rutgers academic building and small scale commercial uses. (26)

Over three years of iterative placemaking - designing, building, studying, revising- the designers have been able to experiment freely with lowcost high-impact interventions, and observe how they engage the public. Sourced from the nearby port, IBC's (Intermediate Bulk Container) are stacked to form towers as the centerpiece of the plaza where jazz concerts and other public events are held. Off to the side is the Grove, a node with moveable tables and chairs and brightly colored umbrellas interspersed with plantings, the "social room" of the site where the exceptionally diverse population in the area comes to lunch and hang out with friends
- city workers, out-patients from the methadone clinic, Rutgers students, neighborhood children. Here the social-bonding agent is a simple upright piano where people from every walk of life love to perform. This small but compelling intervention creates what William Whyte has famously called "triangulation", an urban event stimulating complete strangers to interact as if they knew one another (27).

The pop-up is a work in progress. In Year One the IBC towers supported canopies, and the towers were lit from within to create a nighttime spectacle. Motion sensors would change the light color from cool to warm as people passed. In Year Two the same cubes were reinstalled as vertical planters topped with rainwater-capturing saucers. These green towers and a rain curtain set the stage for a lively, interactive teaching demonstration about the water-based environmental problems facing Camden. In Year Three the green towers are reinstalled and concerts are expanded; health is introduced as a theme, with new food stands, play space, and exercise programming.

During each six-month installation the pop-up park was documented using time-lapse photography from City Hall above, video interviews, ground observations and postcard surveys to identify and map how the park was used and by whom, what worked and did not - methods straight from William Whyte. New ideas surfaced - more music events, more family-centered space, a playground, food carts, and, interestingly, an often-voiced concern over the excessive presence of "police" (potentially mistaken for the uniformed park "ambassadors"). An overwhelming sense of satisfaction and pride infuses the feedback from the users. Says one: "Camden has been neglected for so long... and to have somebody just care enough to give this - it's the smallest thing but the biggest thing". This is a poignant remark, at once validating the project's success and revealing its flaws. Perhaps the intensity of surveillance for research and safety has had the unintended consequence of distancing the place from the users. For all its generosity and focus on the users, the pop-up is "given" to, not co-created with, this hugely underserved community. The interviewee's gratitude shimmers with awareness of a grassroots powerlessness, a recognition forces above and beyond have agenda that chooses - or does not - to serve the interests of the populace. In fact, in an effort to clean up the city center the methadone clinic soon will lose pride of place on the plaza.

\section{RULES OF ENGAGEMENT: CONTEXT, COMMITMENT, AND COLLABORATION}

These three very different cases begin to outline a new conception of how tactical urbanism might be used to advance social justice goals in underserved communities dealing with poverty, unemployment, degraded environments, crime and the breakdown of institutions. However wellmeant or cleverly designed, designer-generated tactical urbanism applied in struggling neighborhoods can be problematic. An ethic of unfettered pro-active intervention tempts off-the-grid designers and ambitious speculators to decide in their own terms what is in the interest of the common good.

To those engaged in social impact design, it may be obvious that any built or proposed intervention should evolve from a deep recognition of how 


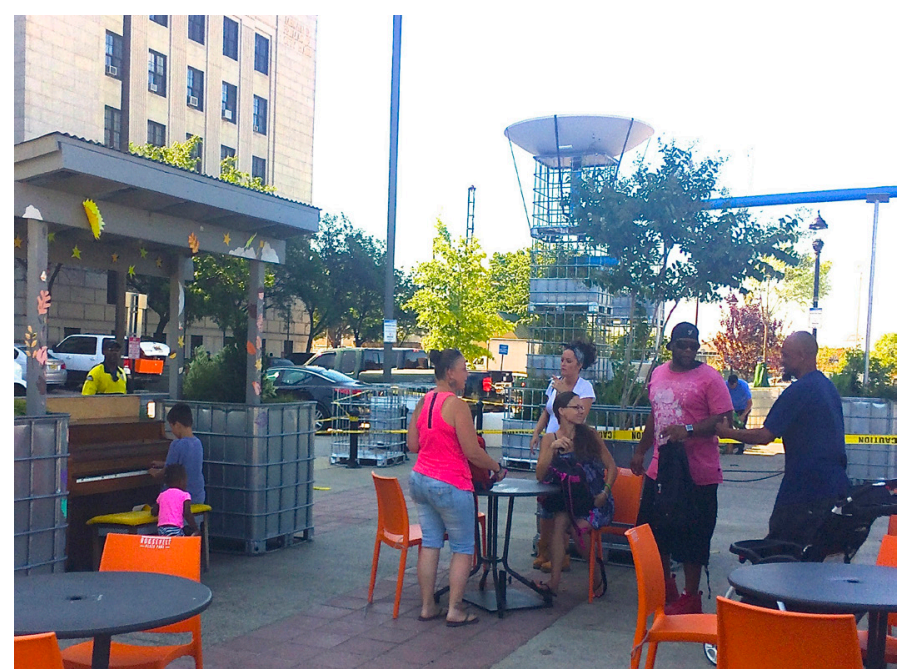

[Figure 4. Year Two. at Roosevelt Plaza Pop-up. "The Grove" with piano and green towers from IBC totes beyond. Photo: S. Harrison

the neighborhood works. Thoughtful designers do have much to offer here. Trained as we are in multi-scale research, representation, and making, we can help a community to create a simultaneous reading of larger systems and locally practiced tactics, suggesting how and where intervention would be most effective. And in Jaime Lerner's terms, "pin-pricks of change", if knowingly administered, can begin to dislodge urban blockages. The work with APM, required constantly resetting our focal length: being immersed enough to identify informal localized practices that could grow into community-owned industries; then mapping the larger forces at play and overwriting them with community-centered opportunity; finding in the DNA of large plans, a nucleus of change.

A commitment to stay with the project, further distinguishes these cases from the typical tactical urbanism project. Whereas in healthy environments, simply "seeding" might reasonably yield a sustainable place, in underserved communities the terrain presents significant obstacles to survival and continuity. The vigorous on-going Roosevelt Park Pop-Up it has taken years of programming, evaluation, redesign and reprogramming for patterns of human-centered civic expression in this once bereft plaza, to take root. Notwithstanding the discomfiting excess of oversight, the annual experiments in Roosevelt plaza have succeeded. Though their LQC tactics were meant to minimize risk for future capital expense, it may be that the vibrancy of change itself is the more valuable contribution to the long-term identity of the place.

Play Lancaster has been also in constant state of change since its inception. Less about a fully formed future vision than about a process that takes full advantage of trial and error, it has become a space that learns and teaches. Intentionally educative, the program challenges its young builders to balance the discipline of making with the porosity of creative thought. Inviting collaboration from all corners of the neighborhood, it also challenges the community to commit to its children. The seeming paradox of play, front and center in the public realm, literally spilling out on the sidewalk of a shopping corridor tells us something important about what our society should value. Is this not what tactical urbanism is meant to do?
Over three years of iterative placemaking - designing, building, studying, revising- the designers have been able to experiment freely with low-cost high-impact interventions, and observe how they engage the public. Sourced from the nearby port, IBC's (Intermediate Bulk Container) are stacked to form towers as the centerpiece of the plaza where jazz concerts and other public events are held. Off to the side is the Grove, a node with moveable tables and chairs and brightly colored umbrellas interspersed with plantings, the "social room" of the site where the exceptionally diverse population in the area comes to lunch and hang out with friends - city workers, out-patients from the methadone clinic, Rutgers students, neighborhood children. Here the social-bonding agent is a simple upright piano where people from every walk of life love to perform. This small but compelling intervention creates what William Whyte has famously called "triangulation", an urban event stimulating complete strangers to interact as if they knew one another.

The pop-up is a work in progress. In Year One the IBC towers supported canopies, and the towers were lit from within to create a nighttime spectacle. Motion sensors would change the light color from cool to warm as people passed. In Year Two the same cubes were reinstalled as vertical planters topped with rainwater-capturing saucers. These green towers and a rain curtain set the stage for a lively, interactive teaching demonstration about the water-based environmental problems facing Camden. (Fig. 4) In Year Three the green towers are reinstalled and concerts are expanded; health is introduced as a theme, with new food stands, play space, and exercise programming.

During each six-month installation the pop-up park was documented using time-lapse photography from City Hall above, video interviews, ground observations and postcard surveys to identify and map how the park was used and by whom, what worked and did not - methods straight from William Whyte. New ideas surfaced-more music events, more family-centered space, a playground, food carts, and, interestingly, an often-voiced concern over the excessive presence of "police" (potentially mistaken for the uniformed park "ambassadors") (28). An overwhelming sense of satisfaction and pride infuses the feedback from the users. Says one: "Camden has been neglected for so long....and to have somebody just care enough to give this - it's the smallest thing but the biggest thing" (29). This is a poignant remark, at once validating the project's success and revealing its flaws. Perhaps the intensity of surveillance for research and safety has had the unintended consequence of distancing the place from the users. For all its generosity and focus on the users, the pop-up is "given" to, not co-created with, this hugely underserved community. The interviewee's gratitude shimmers with awareness of a grassroots powerlessness, a recognition forces above and beyond have agenda that chooses - or does not - to serve the interests of the populace. In fact, in an effort to clean up the city center the methadone clinic soon will lose pride of place on the plaza.

\section{RULES OF ENGAGEMENT: CONTEXT, COMMITMENT, AND COLLABORATION}

These three very different cases begin to outline a new conception of how tactical urbanism might be used to advance social justice goals in 
underserved communities dealing with poverty, unemployment, degraded environments, crime and the breakdown of institutions. However wellmeant or cleverly designed, designer-generated tactical urbanism applied in struggling neighborhoods can be problematic. An ethic of unfettered pro-active intervention tempts off-the-grid designers and ambitious speculators to decide in their own terms what is in the interest of the common good.

To those engaged in social impact design, it may be obvious that any built or proposed intervention should evolve from a deep recognition of how the neighborhood works. Thoughtful designers do have much to offer here. Trained as we are in multi-scale research, representation, and making, we can help a community to create a simultaneous reading of larger systems and locally practiced tactics, suggesting how and where intervention would be most effective. And in Jaime Lerner's terms, "pin-pricks of change", if knowingly administered, can begin to dislodge urban blockages. The work with APM, required constantly resetting our focal length: being immersed enough to identify informal localized practices that could grow into community-owned industries; then mapping the larger forces at play and overwriting them with community-centered opportunity; finding in the DNA of large plans, a nucleus of change.

A commitment to stay with the project, further distinguishes these cases from the typical tactical urbanism project. Whereas in healthy environments, simply "seeding" might reasonably yield a sustainable place, in underserved communities the terrain presents significant obstacles to survival and continuity. The vigorous on-going Roosevelt Park Pop-Up it has taken years of programming, evaluation, redesign and reprogramming for patterns of human-centered civic expression in this once bereft plaza, to take root. Notwithstanding the discomfiting excess of oversight, the annual experiments in Roosevelt plaza have succeeded. Though their LQC tactics were meant to minimize risk for future capital expense, it may be that the vibrancy of change itself is the more valuable contribution to the long-term identity of the place.

Play Lancaster has been also in constant state of change since its inception. Less about a fully formed future vision than about a process that takes full advantage of trial and error, it has become a space that learns and teaches. Intentionally educative, the program challenges its young builders to balance the discipline of making with the porosity of creative thought. Inviting collaboration from all corners of the neighborhood, it also challenges the community to commit to its children. The seeming paradox of play, front and center in the public realm, literally spilling out on the sidewalk of of a shopping corridor tells us something important about what our society should value. Is this not what tactical urbanism is meant to do?

\section{ACKNOWLEDGEMENT}

The author gratefully acknowledges Temple University for its generous support of her research, presentation and publication of this work through a Summer Research Grant.

\section{ENDNOTES}

1. Merker, Blaine (2010) "Taking Place: Rebar's absurd tactics in generous urbanism." In Hou, Jeffrey, Ed. Insurgent Public Space: Guerrilla Urbanism and the Remaking of Contemporary Cities. New York: Routledge.
2. Lydon, Mike and Anthony Garcia (2012). Tactical Urbanism 2: Short Term Action, Long Term Change. Washington: Island Press.

And Silberberg, Susan (2013) Places in the Making, how placemaking builds places and Communities, https://dusp.mit.edu/sites/dusp.mit.edu/files/attachments/project/mitdusp-places-in-the-making.pdf. MIT Department of Urban Studies and Planning Accessed May 12, 2016

3. Merker, 42

4. Three high-profile exhibits were mounted between 2008 and 2013: Actions: What You Can Do With the City (Canadian Center for Architecture); Uneven Growth: Tactical Urbanisms for Expanding Megacities (Museum of Modern Art) and Spontaneous Interventions: design actions for the common good (American Pavilion at the Venice Architecture Biennale)

5. Mould, Oli "Tactical Urbanism: The New Vernacular of the Creative City." In Geography Compass 8.8 (2014): 529-539

6. Chase, J., M. Crawford and J. Kaliski (1999) Everyday Urbanism. New York: Monacelli Press.

Hou, Jeffrey, Ed . (2010) Insurgent Public Space: Guerrilla Urbanism and the Remaking of Contemporary Cities. New York: Routledge

Roy, Ananya and Nezzar AlSayyad, (2004) Urban Informality: Transnation Perspectives from the Middle East, Latin America and South Asia. Oxford: Latham Press..

7. De Certeau, Michel (1993) "Walking in the City." In Simon During Ed. The Cultural Studies Reader. London: Routledge.

8. Smithson, Alison, Ed. (1968) Team 10 Primer. Cambridge, MA: MIT Press.

9. Whyte, William (1980) The Social Life of Small Urban Spaces, New York: The Conservation Foundation.

10. I use placemaking and tactical urbanism as co-related terms that both refer to iterative processes that support human centered use of public space. Generally, the spatial tactic is a (smaller) tool for (larger) placemaking.

11. Notable among these are Corona Plaza in Queens, NY; the Detroit Alleys Project; the Rebuild Foundation in St. Louis, the Village of Arts and Humanities in Philadelphia.

12. Project for Public Places website http://www.pps.org/reference/lighter-quicker-cheaper/ Accessed 2 June, 2016..

13 Florida, Richard (2012) The Rise of the Creative Class. New York: Routledge.

14. Huffington Post, "21 Ways Philadelphia is the Coolest City in America" http://www. huffingtonpost.com/larissa-and-michael-milne/25-reasons-why-philadelph_b_7471458. html. Accessed 1 June 2016

15. Douglas, Gordon, "Do-it-yourself Urban Design in the Help Yourself City." In Architecture Magazine: Spontaneous Interventions, August, 2012, 44.

16 See also: Douglas, Gordon, "The formalities of informal improvement: technical and scholarly knowledge at work in do-it-yourself urban design." Journal of Urbanism: International Research on Placemaking and Urban Sustainability (2015): 1-18.

16. See Merker, in Hou.

17. Williams, Damon C. "Gentrification dispute revived" Philadelphia Tribune. February 20, 2016, http://www.phillytrib.com/news/gentrification-dispute-revived/article_e3d6f0766878-5e92-9cb5-d3d94a3cfa8b.html. Accessed 3 June 2016

18. Luiz, Nila Iris and Andrew Frischkoft, "Quality of Life Plan", Asociacion Peurtorriquenos en Marcha, 2010.

19. Ho, Cathy, "Spontaneous Interventions: Design Actions for the Common Good." In Architecture Magazine: Spontaneous Interventions, August, 2012: 24..

20. Architecture graduate students participating in the studio (Arch 8012) included: Joe Kott, Matt McCall, Collin Phillips, Nick Scasaro, and Dan Vallachi.

21. Lerner, Jaime (2014) Urban Acupuncture: Celebrating pinpricks of change that enrich city life. Washington: Island Press. grande, Marco (2013) Biourban Acupuncture. Treasure Hill of Taipei to Artena, Rome: International Society of Biourbanism.

22. An important case study is the work at Greater Cleveland Circle presented to the class by University Architect, Margaret Carney..

23. Portions of the case studies of "Play Lancaster" and Roosevelt Plaza Pup-Up have been published in an article for Context, the Journal of AIA Philadelphia (Harrison 2016).

24. Alexander, Christopher, "A City is not a Tree." In Design, London: Council of Industrial Design 206, 1966: 12.

25. Giliam, Alex, Personal interview, January 22, 2016.

26. Lydon, Mike and Anthony Garcia (2012). Tactical Urbanism 2: Short Term Action, Long Term Change. Washington: Island Press.

27. Whyte, 94-101.

SikoraWellsAppel, “Activating Roosevelt Plaza Park, Placemaking in Camden's Public Spaces." Unpublished report, 2015.

28. Sikora, Joseph, Personal Interview Feb. 3, 2016.

29. SikoraWellsAppel, 4. 